\title{
Utilization of Solar Water Heaters to Reduce Residential Electrical Load
}

\author{
Majid S. Al-Hafidh'1, Mudhafar A. Al-Nama ${ }^{2}$ and Azher S. Al-Fahadi ${ }^{3}$ \\ ${ }^{1}$ Department of Electrical Engineering, Mosul University, Mosul, Iraq \\ ${ }^{2}$ Department of Computer Engineering and Technology, Al Hadbaa University, Mosul, Iraq \\ ${ }^{3}$ Department of Electrical Engineering, Mosul University, Mosul, Iraq
}

\section{A B S T R A C T}

Residential electrical load in Iraq can be divided into five components, lighting, home appliances, heating, cooling, and water heating. Water heating component represents the largest residential electric load component in Iraq. The current research aims to test the possibility of using solar water heaters to supply hot water to residential units. Solar water heaters were added to a number of residential units in Mosul city, with the addition of a small electrical heater to provide supplementary heating. The readings of the total energy consumed, the energy consumed in the supplementary heating, the amount of water consumed and the water temperature in the solar heated tank, were recorded each day for a full year. The results were analyzed and compared with the case without the addition of solar heaters. The addition of solar water heater with supplementary heating leads to the reduction of the total consumption up to one-fifth of the total energy $(19.19 \%)$.

Index Terms: Iraqi Residential Electrical Load, Residential Electrical Load, Solar Energy, Solar Water Heaters

\section{INTRODUCTION}

Electrical loads can be divided into several categories, including residential, industrial, commercial, and government. These components vary in the electrical system depending on the economic, political, social state of the country, etc.

In previous research, diversity factor was been studied in the Iraqi electricity distribution system. The study shows that household electrical loads have grown at high rates exceeded the standard values for stable systems [1]. Another study conducted aims to use artificial neural network technology to guess household electrical loads [2].

\begin{tabular}{|l|l|}
\hline \multicolumn{2}{|c|}{ Access this article online } \\
\hline DOI: 10.21928/uhdjst.v1n1y2017.pp23-26 & $\begin{array}{l}\text { E-ISSN: 2521-4217 } \\
\text { P-ISSN: 2521-4209 }\end{array}$ \\
\hline $\begin{array}{l}\text { Copyright @ } 2017 \text { Al-Hafidh, et al. This is an open access article } \\
\text { distributed under the Creative Commons Attribution Non-Commercial } \\
\text { No Derivatives License 4.0 (CC BY-NC-ND 4.0) }\end{array}$ \\
\hline
\end{tabular}

Residential loads represent biggest components in the Iraqi electrical systems, due to low industrial and commercial loads components. Residential electrical loads consist of many components, household appliances, lighting, space heating, cooling, and water heating. A previous field survey study was conducting in the city of Mosul to specify these components. The study found that the water heating component was the largest component, 32.29\% [3].

The current research aims to test the possibility of using solar water heaters to supply hot water in the housing units. Solar water heaters were added with low rating electrical heater to provide supplementary heating for a number of residential units in Mosul city. The total energy consumed, the energy consumed in the supplementary heaters, the amount of water consumed, and the water temperature in the solar heater tank registration were recorded. Readings recorded daily for 1 full year. The readings were analyzed to find the percentage of water heating component. Furthermore, the change with the months of the year is compared with the previous

\section{Corresponding author's e-mail: el_noor2000@yahoo.com}


study (without solar heated). The results, the analysis, and comparison are listed in the following paragraphs.

\section{THEORETICAL BASIS}

Renewable energies represent suitable alternatives to solve the problems resulting from high energy consumption rates (especially electricity). Renewable energies (wind energy, solar energy, hydropower, etc.) can be used to generate thermal energy, kinetic energy, electrical energy, etc.

Many researchers have been conducted to study the solar energy falling in different areas in Iraq. The studies included which study all Iraqi areas and gave illustrations of solar energy for different seasons of the year [4]. Other studies Al-Salihi et al. and Ali have been conducted to certain areas in Iraq such as Baghdad, Mosul and Kirkuk, Ramady, etc. [5], [6].

Solar energy has been used for water heating in many developing countries. Mohammed, et al., 2011, study the possibility of using solar energy to heat water for the use of 25 people in Baghdad using a solar panels collectors of $10 \mathrm{~m}^{2}$ capacity and a storage tank of $600 \mathrm{~L}$ capacity [7]. The study concluded the possibility of using solar energy to provide $69 \%$ of the hot water using solar heaters, by providing more than $60 \%$ in the winter, and more than $70 \%$ in the summer. It is well known that in summer no hot water is needed (June, July, August, and September).

Another study uses TRNSYS software to model and verify a direct solar water heating system in Baghdad, Iraq. The study aims to meet the demand of hot water for 25 persons using $10 \mathrm{~m}^{2}$ of a flat plate collector and $600 \mathrm{~L}$ storage tank [7].

\section{RECORDING READINGS}

A group of houses (8 homes) was selected in the technical institute's foundation. A solar water heater has been added for each residential unit. A low rating electrical heater of $1 \mathrm{~kW}$ is used to provide supplementary heating. Fig. 1 shows one of the solar water heating systems used in the study. The system consists of two flat plate collectors each of the dimension $80 \mathrm{~cm} \times 150 \mathrm{~cm}$ and storage tank of hot water with a capacity of $180 \mathrm{~L}$. The flat plate collector and the storage tank capacity can be changed to match the consumers hot water demand.

Each solar water heater was equipped with a set of meters. The meters measure the energy consumed in the supplementary

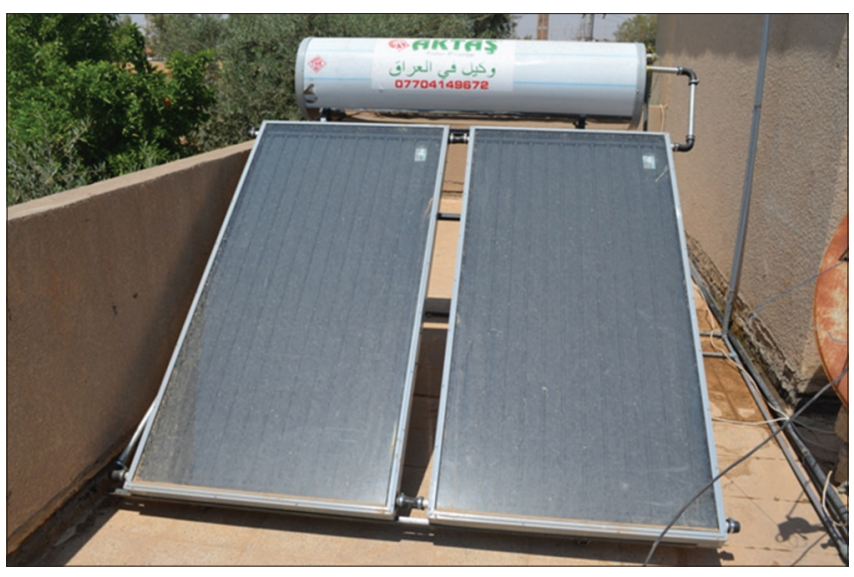

Fig. 1. One of the solar water heating systems used in the study

heaters, the amount of hot water consumed, and the water temperature in the storage tank. The supplementary heating energy and hot water consumed were recorded, once every 2 days.

Furthermore, an ammeter is used to measure the current drawn in the house units. The current and the water temperature in the storage tank readings have been registered at three different times at the morning, afternoon, and at night. As well as the total energy consumption in the residential units reading was recorded. Total energy reading was recorded, once every 2 days.

Previous readings were recorded for the entire year. Recorded readings were used in the analysis to get the results described in the following paragraphs. Calculations can be performed based on the distribution of the foundations weekly or monthly. The calculations discussed in the results based on a semimonthly period, as well as monthly.

\section{RESULTS AND ANALYSIS}

Electrical load in Iraq is strongly influenced by weather climate changes where the high temperature in the summer leads to increase the electrical load as a result of using the cooling devices. Furthermore, the low temperature in winter leads to increase electrical load as a result of using space heating and water heating whereas mild temperatures in spring and autumn lead to a reduction of electrical load, which represents the lowest throughout the year.

In general, a large amount of solar energy falls on Iraq, and especially in Mosul city. It is clear that the amount of solar energy falling vary with seasons, where maximum energy 
falls in the summer. The minimum fallen energy is winter. The statistics show that the hours of solar brightness in Iraq, during the winter is represented $50-60 \%$ of daylight hours. Lowest rate happens to solar brightness hours in the month of January with $4.87 \mathrm{~h}$. While the hours of solar brightness in summer represents $90 \%$ of the daylight hours, with a maximum brightness of the sun hours in the month of July $12.31 \mathrm{~h}$. Fig. 2 shows the average daily solar energy falling and the rate of solar brightness hours versus months of the year in the city of Mosul. Less solar energy occurs in the month of January and reaches $7.22 \mathrm{MJ} / \mathrm{m}^{2}$-day. The maximum solar fallen in the month of June and reach $26.32 \mathrm{MJ} / \mathrm{m}^{2}$-day (Iraqi Air Adversity 1989).

Supplementary heating energy changes with temperature in the proportion of different seasons, as well as with the intensity of incoming solar radiation changes. Therefore, the need for supplementary energy heating in winter becomes the highest in the whole year. Fig. 3 illustrates the monthly supplementary rated heating in the year. It shows that there

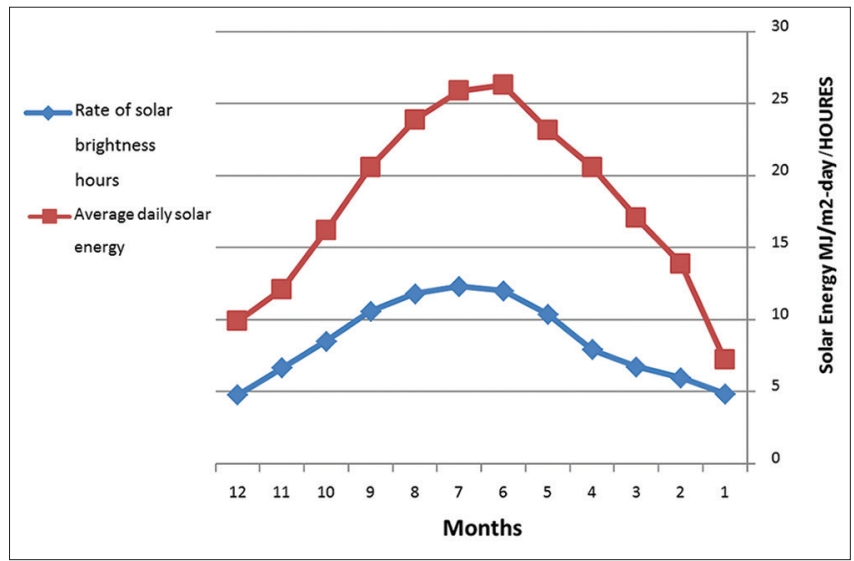

Fig. 2. Average daily solar energy falling and the rate of solar brightness hours versus months of the year in the city of Mosul

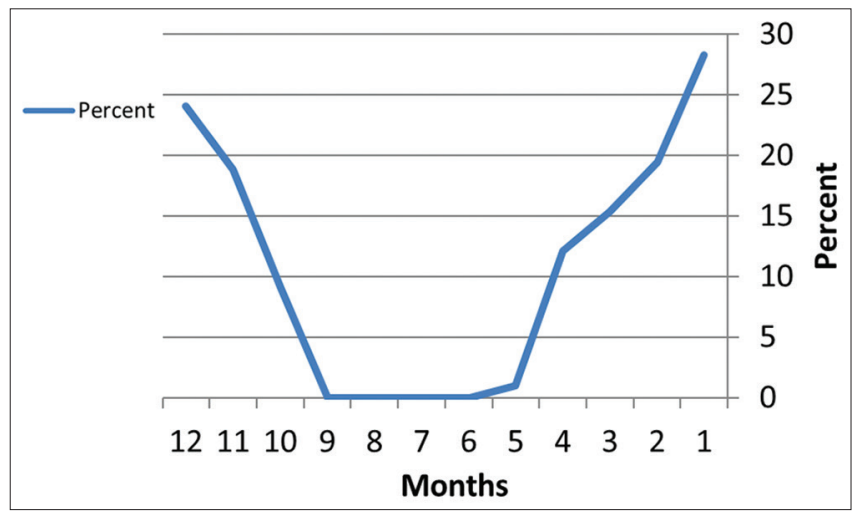

Fig. 3. Supplementary heating rate of the months of the year is no need for supplementary heating during summer. As well as it decreases in spring and autumn.

The supplementary heating energy rate was calculated for a period of semimonthly to compare it with the energy consumed in the water heating (without the addition of solar heated). Fig. 4 shows the energy consumed in the water heating with and without solar water heating. It is clear from the figure the great difference between the amount of supplementary heating energy used with solar water heater and the case without using it. Also the times in which maximum benefits of adding solar heater is achieved. As well as there is no need to heat the water the majority of the summer. The maximum reduction ratio result during the spring and autumn. While reduction rates are less during winter than in the case of spring and autumn.

Table I summarizes the percentage of water heating component with the addition of solar water heaters and without them. The table includes the amount of the proportion of water heating component for the case of high consumption, the average consumption and the low

\begin{tabular}{lcccc}
\multicolumn{3}{c}{ TABLE I } \\
$\begin{array}{l}\text { Percentage of the Components of Household } \\
\text { Electrical Load and the Amount of Little and } \\
\text { Average Total and High Consumption }\end{array}$ \\
\hline Rate \% & \multicolumn{3}{c}{ Consumption } \\
\cline { 2 - 5 } Case & Low \% & Average \% & High \% \\
\hline $\begin{array}{l}\text { With solar } \\
\text { heater }\end{array}$ & 13.1 & 13.1 & 9.85 & 11.61 \\
$\begin{array}{l}\text { Without } \\
\text { solar heater }\end{array}$ & 32.3 & 32.29 & 13.39 & 30.4 \\
\hline
\end{tabular}

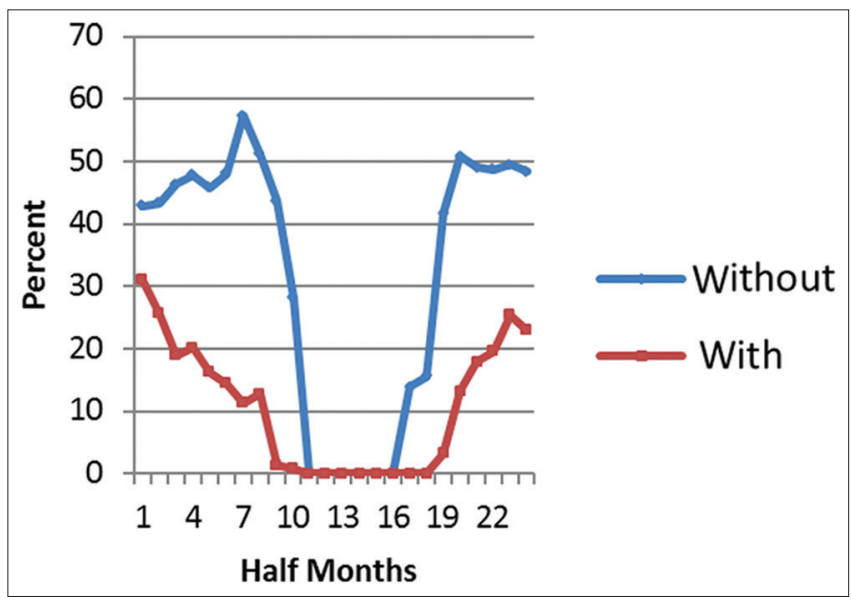

Fig. 4. Energy consumed in the water heating with and without solar water heating 
consumption, in addition to the average consumer. Evidenced by the average value of the added solar water heater leads to a reduction in the total consumption by $19.19 \%$.

\section{CONCLUSION}

The current research shows a reduction in water heating component in residential units electrical load using solar water heaters. A solar water heater was added to a number of residential units in the city of Mosul in northern Iraq. A small rating heater was added to the solar water heaters to provide supplementary heating. The percentage of supplementary heating component compared with total electrical energy consumption in each housing units was calculated. As well as the percentage of supplementary heating component compared with total electrical energy consumption in all housing units. The results illustrate the possibility of obtaining a holistic reduced by $19.19 \%$.

The solar water heaters used have a standard specifications, while the hot water needs of the residential units vary as a result of differing ages and number of occupants (consumer), etc. Which must leads to change some specifications of the solar water heaters, such as solar heater flat plane area and hot water storage volume. The solar water heaters specification can be studied to get a further reduction in the supplementary heating component.

\section{FUTURE WORK}

The registered readings of the water consumed can be used to find a general model for hot water demand for different houses units. This general model can be used to design the suitable heating system to meet the hot water demand for any consumer.

Furthermore, the water temperature of the storage tank can be used to wake a general model for heat transfer for the heating system. This model can be used to improve the system efficiency.

\section{THANKS AND APPRECIATIONS}

The researchers express their deep gratitude and thanks to the administration and the engineers of the general management for north region electrical distribution for their valuable help and cooperation throughout this work and fruitful discussion and suggestions made among the different study stages.

\section{REFERENCES}

[1] M. A. Al-Nama, M. S. Al-Hafid and A. S. Al-Fahadi. "Estimation of the diversity factor for the Iraqi distribution system using intelligent methods." Al-Rafidain Engineering, Mosul, vol. 17, no.1, pp. 14-21, 2009.

[2] M. A. Al-Nama, M. S. Al-Hafid and A. S. Al-Fahadi. "Estimation of the consumer peak load for the Iraqi distribution system using intelligent methods." Iraqi Journal for Electrical and Electronic Engineering, vol. 7, no. 2, pp. 180-184, 2011.

[3] M. S. Al-Hafid, M. A. Al-Nama and A. S. Al-Fahadi. "Determination of Residential Electrical Load Components in Iraqi North Region." Iraqi Journal for Electrical and Electronic Engineering, Basra, Iraq: Sent for Publication.

[4] M. Z. Mohammed, M. A. Al-Nema and D. A. Al-Nema. "Seasonal distribution of solar radiation in Iraq." Proceeding of the Conference on the Physics of Solar Energy. Arab Development Institute, Special Publication, Tripoli, 1977.

[5] A. M. Al-Salihi, M. M. Kadum and A. J. Mohammed. "Estimation of global solar radiation on horizontal surface using routine meteorological measurements for different cities in Iraq." Asian Journal of Scientific Research, vol. 3, no. 4, pp. 240-248, 2010.

[6] F. A. Ali. "Computation of solar radiation on horizontal surface over some Iraqi cities." Engineering and Technical Journal, vol. 29, no.10, pp. 2026-2042, 2011.

[7] M. N. Mohammed, M. A. Alghoul, K. Abulqasem, A. Mustafa, K. Glaisa, P. Ooshaksaraei, M. Yahya, A. Zaharim and K. Sopian. "TRNSYS simulation of solar water heating system in Iraq." Recent Researches in Geography, Geology, Energy, Environment and Biomedicine, pp. 153-156, Jul. 2011. 